\title{
Contents, Vol. 177, 1978
}

\section{No. 1}

Original Paper · Origînalarbeiten $\cdot$ Travaux originaux

Schwartzenberg, T.; Vancea, P. P.; Scânteie, V.et Covic, M.: Problèmes de diagnostic et detraitement dans un cas clinique de dyspla-sie oculo-auriculaire associée à la dysostosemandibulo-faciale (syndrome de France-schetti-Goldenhar) 1

Saracco, J. B.; Cornand, A.; Estachy, G. etLlavador, M.: Le vitré dans Гaphakie 13

Mortada, A.: Cutting of the Encircling Silastic Band: Indications and Overcoming Difficulties. The Half Encircling Band Effect .. 22

Yamade, S. and Kitagawa, A.: Malignant ofthe Lacrimal Sac

Naeser, P.: Optic Nerve Changes in ChorioidalMalignant Melanoma

Damaske, E.: Tektonische Keratoplastik beiInfizierter Elliotscher Trepanation

Clinicopathologic Case Reports

Knöbel, H. und Domarus, D. von: Eosino-philes Granulom der Koojunktiva

Spinak, M. and Dembitzer, H. M.: UnusualIntracytoplasmic Inclusions in a Case ofIdiopathic Scleritis 53

No. 2

Original Paper · Originalarbeiten . Travaux originaux

Uchida, K. and Honda, Y.: Opsoclonus Inducing Retinal Detachment with a MacularHole 61

Amemiya, T.; Yoshida, H.; Harayama, K.;Miki, M., and Koizumi, K.: Long-Term Results of Retinal Detachment Surgery 64

Demeler, U.: Irisangiographische Besonderhei-ten bei malignen Melanomen der Aderhaut 70 Merin, S.; Ber, I., and Ivry, M.: Retinal Ischemia (Capillary Nonperfusion) in DiabeticRetinopathy of Patients With and WithoutSystemic Hypertension 76 Reale, F.; Delfini, R., and Cintorino, M.: AnIntradiploic Meningioma of the OrbitalRoof: Case Report 82

Francois, J.; Verbraeken, H.; Gabriel, P. etWille, C: Syndrome myasthénique aprèstraitement peroral à la pénicillamine $\quad 88$

Orsoni, J. G. et Medioli, F. C: Tentative ettentation d'interpréter comme une manifestation psychosomatique une paralysie de $\Gamma$ accommodation 92

Safran, A.B.; Korol, S. et Gauthier, G.: Lespotentiels évoqués visuels chez les patientssuspects de sclérose en plaques 100

Focosi, M. and Parducci, F.: About a Particular Interaction of the Fixating Eye in Strabisme Amblyopia after Treatment ... 109

Clinicopathologic Case Reports

Bergström, K.; Enoksson, P.; Gamstorp, I., and Naeser, P.: Haemangio-Endotheliomaof the Orbit 115

No. 3

Original Paper $\cdot$ Originalarbeiten $\cdot$ Travaux originaux 
Francois, J.: Erosion dystrophique récidivantede Гépithélium cornéen

Bijsterveld, O. P.; Jong, J. C. de; Muzerie, C. J., and Wermenbol, A. G.: Pharyngo-conjunctival Fever Caused by AdenovirusType 19 134

Merin, S.; Ber, I., and Ivry, M.: Retinal Ischemia (Capillary Nonperfusion) and

RetinalNeovascularization in Patients with Diabetic Retinopathy 140

Knöbel, H. und Demeler, U.: Keratoplastik beiKindern und Jugendlichen 146

Jónasson, F.: Orbital Plasma Cell Tumours 152

Francois, J.: Combined Operation for Cataractand Glaucoma 158

Francois, J. and Victoria-Troncoso, V.: Histology of the Epithelium of the Normal

andCataractous Lens 168

IV

Index

Clinicopathologic Case Reports

Schmitt, H.; Ristow, W. und Bohl, J.: Akuteorbitozerebrale Phykomykose 176

No. 4

Original Paper · Originalarbeiten . Travaux origi $\pi$ aux

Dolezalová, V.: Saisonrhythmus infektiöserAugenkrankheiten in Nordafrika

Amemiya, T. and Yoshida, H.: Macular Holein Diabetic Maculopathy 188

Hamann, K.-U.: Periodisch Alternierender Nystagmus 192

Smith, V. C; Pokorny, J., and Newell, F. W.: Autosomal Recessive Incomplete Achromatopsia with Protan Luminosity Function ... 197

Sayegh, F.; Samerra'e, S., and Khateeb, M.: Clinical Trial of Topical Disodium Chro-moglycate in Vernal Keratoconjunctivitis . 208

Francois, J.; Victoria-Troncoso, V., and Can-su, K.: Tissue Culture of the Epithelium of the

Normal and Cataractous Adult Lens 214

Clinicopathologic Case Reports

Hinzpeter, E. N.; Knöbel, H., and Freund, J.:

Spontaneous Haemophthalmus in Leukaemia 224 Domarus, D. v. und Mitschke, H.: Primäres

alveolares Weichteilsarkom der Aderhaut.

Ophthalmopathologie und Histogenese .. 229 Book Reviews · Buchbesprechungen · Livres

nouveaux 236

No. 5

Original Paper . Originalarbeiten . Travaux originaux

Orzalesi, N.; Lostia, S.; Loi, M., and Tulli, P.:Associated Malformations of the Eye andthe Ear.

The Goldenhar Syndrome 237

Busse, H. und Schiffer, H.-P.: Melanozytomder Papille 245

Landolfo, V.; Albini, L., and De Simone, S.:Senile Macular Degeneration and Alteration of the

Metabolism of the Lipids 248

Pesando, P.; Nuzzi, G., and Maraini, G.: Vertical Retraction Syndrome 254

Grounauer,P. A.; Burckhardt,C. W.; Van Toi, V. et Parapini, G: Le syndrome

contusifintrarétinien existe-t-il? 260

Kovács, B. and Vastag, O.: Fluoroangiogra-phic Picture of the Acute Stage of the Retinal Lesion in Subacute Sclerosing Panen-cephalitis 264

Demeler, U.: Irisangiographie bei der Mem-brana pupillaris persistens $\quad 270$ 
Mierdel, P. and Marré, E.: Objective Detection of Reversible Deficiencies in Glaucoma by Means of VECP 276

Keiner, E. C. J. F.: Spontaneous Recovery inMicrostrabismus $\quad 280$

Pinckers, A.: Lanthony's New Color Test.Part I 284

Varia 292

No. 6

Original Paper · Originalarbeiten . Travaux originaux

Gerhard, J. P.; Willard, D.; Risse, J.F.; Kuss, J. J. et Messmer, J.: Avenir visuel du premature 293

Gailloud, C. et Raimondi, S.: Diagnostic des tumeurs intraoculaires: test au phosphore-32 304

Brancato, R.; Giarelli, L., and Mahnic, F.:Presence of Endoarterial Dispositives Regulating

Retinal Blood Circulation 307

Pinckers, A.: Lanthony's New Color Test ... 311

Palimeris, G.; Chimonidou, E., and Velissaro-poulos, P.: On the Management of Congenital

Cataract with Dardenne's Equipment 317

Grote, P.: Ergebnisse der transtrabekulärenIridektomie

323

Grote, P.: Versuche zur Verminderung des Operationstraumas bei der Trabekulotomie 329

Clinicopathologic Case Reports

Bujara, K.; Domarus, D. v., and Demeler, U.: Adenoma of the Iris Pigment Epithelium . 336

Varia 341

Erratum 341

I. Index rerum 342

Index autorum 